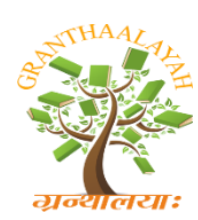

INTERNATIONAL JOURNAL OF RESEARCH GRANTHAALAYAH A knowledge Repository

Social

\title{
A REVIEW OF ENGLISH TEXTBOOK ENTITLED "SKILLFUL: READING AND WRITING, STUDENT'S BOOK 1" BY DAVID BOHLKE AND DOROTHY ZEMACH
}

\author{
Thunyalak Polsuk $^{* 1}$, Nutprapha K. Dennis, Ph.D. ${ }^{2}$ \\ ${ }^{* 1,2}$ English Department, Ubon Ratchathani Rajabhat University, Thailand
}

DOI: https://doi.org/10.29121/granthaalayah.v5.i5.2017.1844

\begin{abstract}
This study aims to evaluate the usefulness of a commercial textbook entitle "Skillful: Reading \& Writing, Student's Book 1", written by David Bohlke with Dorothy E. Zemach as a series consultant, published by Macmillan publisher. The study also explores the appropriateness for considering to teaching university EFL students. The result of this study assists English teachers in choosing textbooks which will be most appropriate to the learners at various level to develop their reading and writing skill. It is also a guideline for English teachers to evaluate the textbook they are using to teach EFL students in reading and writing class for their next semester. Moreover, the set of questions as research instrument in the study, English teachers can adapt into their curriculum for material development for other subjects of English learning. To conclude and answer research question, this textbook is appropriate to teach Thai university EFL students after considering by the researcher.
\end{abstract}

Keywords: English Textbook; Textbook Review; Reading and Writing.

Cite This Article: Thunyalak Polsuk, and Nutprapha K. Dennis. (2017). "A REVIEW OF ENGLISH TEXTBOOK ENTITLED "SKILLFUL: READING AND WRITING, STUDENT'S BOOK 1" BY DAVID BOHLKE AND DOROTHY ZEMACH.” International Journal of Research - Granthaalayah, 5(5), 116-124. 10.29121/granthaalayah.v5.i5.2017.1844.

\section{Introduction}

English language plays an important role for communication. English textbook has several factors affecting students' motivation to learn English. A variety of course book in the market makes it difficult to select a suitable one for specific class. This study aims to investigate a textbook produced by one of the most famous publishers of English textbooks for EFL learners, "Skillful: Reading \& Writing, Student's Book 1", written by David Bohlke, Dorothy E. Zemach as series consultant. 
Crawford (2002) explained that in selecting classroom materials, practitioners needed to look carefully at the principles underpinning such materials to ensure that they contribute positively to the learning environment. In order to choose an English textbook for the class, it is crucially significant that the teacher identify the problems the student have and to understand their needs and interests.

This research will examine the textbook used in English reading and writing whether it is appreciate to the level of English proficiency of the students and their needs and interests.

\subsection{Purpose of the Study}

This study aims to evaluate the usefulness of a commercial textbook entitle "Skillful: Reading \& Writing, Student's Book 1", written by David Bohlke with Dorothy E. Zemach as a series consultant, published by Macmillan publisher. The study also explores the appropriateness for considering to teaching university EFL students.

\subsection{Scope and Limitation of the Study}

The study searches for usefulness and appropriateness of the textbook using a set of questions invented by Breen (1985) and Candlin (1982) from University of Lancaster/Macquarie University. The purpose of set of questions is to use to assist teachers to choose teaching material. The researcher adapted the set of questions to fit and explore the answer only for EFL classroom setting in Thailand. The data of the study collected only from the researcher's perspective based on the theories, criteria, and checklist mentioned in this study. The textbook used to evaluate and review in the study is "Skillful: Reading \& Writing, Student's Book 1". The results of the study will not be generalized to other book in the "Skillful: Reading and Writing" series; they are Foundation, level 2, level 3, and level 5.

\subsection{Significant of the Study}

The results of this study can assist English teachers in choosing textbooks which will be most appropriate to the learners at various level to develop their reading and writing skill. It can be also a guideline for English teachers to evaluate the textbook they are using to teach EFL students in reading and writing class for their next semester. Moreover, the set of questions as research instrument in the study, English teachers can adapt into their curriculum for material development for other subjects of English learning.

\subsection{Definition of Key Terms}

English Textbook refers to an English textbook entitled "Skillful: Reading \& Writing, Student's Book 1" / Textbook Review refers to a review and analyze a chosen textbook in the present study. I Reading and Writing refers to English reading and writing skills focused on the textbook used in this study. 


\section{Materials and Methods}

This study focused on evaluating an English textbook for reading and writing, entitled "Skillful: Reading \& Writing, Student's Book 1", written by David Bohlke with Dorothy E. Zemach as a series consultant, published by Macmillan publisher. A set of questions constructed by Breen (1985) \& Candlin (1982) was adapted to use for data collection in the study. The data from this study was qualitative and quantitative.

\subsection{Setting and Material of the Study}

Material used in this study is "Skillful: Reading and Writing, Student's Book 1". Skillful: Reading \& Writing is, Macmillan Academic Skills, textbook series focuses on reading and writing skill. The book focuses on the two skills to give presentation, instant practice, and complete immersion in those language skills. The book offers students the opportunity to develop language skills by presenting them with ideas from today's world, while building critical thinking skills that are vital for academic success. The book is taken further with a focus on study skills, providing students with practical guidance and support, and building confidence for independent learning throughout their university career.

Skillful: Reading \& Writing, Student's Book 1 also offers; a comprehensive digital component including a page-faithful Digitbook and Skillful practice area with interactive activities and video material, two opportunities in each unit to engage critically with issues within texts and to consider concepts beyond the superficial meaning, systematic development of practical study skills through realistic scenarios, critical thinking skills, such as evaluating and synthesizing information.

\subsection{Research Instrument}

Research instrument used in this study to collect data was a checklist to collect and examine the content of the textbook "Skillful: Reading \& Writing: Students' Book 1".

\subsection{Data Collection and Analysis}

The data was drawn from "Skillful: Reading \& Writing: Student's Book 1" and collected by skimming and scanning through the textbook, listing the topics and content, examining the organization of the textbook, listing the main sections and sub-section, listing of examples of reading texts, reading skills, vocabulary skill, grammar, writing skill, writing task, digibook video, study skills of the textbook. After the collected data had been categorized, the researcher analyzed all the data in both quantitatively and qualitatively analyzed to find out the appropriateness of the textbook for considering to teaching university EFL students.

\section{Results and Discussions}

Overview of the Textbook: Contents of "Skillful: Reading and Writing, Student's Book 1"

Unit 1: Character 
Reading Texts

1) Are you a natural leader? / Psychology

2) The hero within / Literary studies

Reading Skills

Pre-reading: Previewing

Close: Using pronouns

Vocabulary Skill: Using examples to find meaning

Grammar: The simple present tense

Writing Skill: Writing topic sentences

Writing Task: Describing a hero

Digibook Video Activity: What makes a hero?

Study Skills: Setting up a study space

Unit 2: Time

Reading Texts

1) A matter of time / Human behavior

2) What time is it? / History

Reading Skills

Close: Identifying the author's purpose

Global: Skimming

Vocabulary Skill: Organizing new words nouns and verbs

Grammar: Verbs followed by infinitives and gerunds

Writing Skill: Understanding sentence patterns

Writing Task: Describing how to achieve a goal

Digibook Video Activity: Time flies as you get older

Study Skills: Writing for the fearful

Unit 3: Home

Reading Texts

1) Home is where the heart is / Anthropology

2) Home automation / Technology

Reading Skills

Close: Highlighting

Close: Annotating

Vocabulary Skill: Using explanations to find meaning

Grammar: There is / are (+quantifier) + noun

Writing Skill: Brainstorming / word maps

Writing Task: Describing your home

Digibook Video Activity: How our homes have changed

Study Skills: Reviewing and practicing vocabulary

Unit 4: Size

Reading Texts

1) Fuel of the sea / Ecology

2) Size doesn't matter / Urban planning

Reading Skills 
Pre-reading: Predicting

Close: Making inferences

Vocabulary Skill: Using definitions to find meaning

Grammar: The present progressive tense

Writing Skill: Writing compound sentences

Writing Task: Describing how your neighborhood is changing

Digibook Video Activity: Reaching for the skies

Study Skills: Process Writing

Unit 5: Patterns

Reading Texts

1) Time for a change / Psychology

2) The Fibonacci sequence / Anthropology

Reading Skills

Close: Determining main ideas and supporting details

Close: Taking notes

Vocabulary Skill: Adding prefixes for negation

Grammar: Giving advice and making suggestions

Writing Skill: Using end punctuation and capitalization

Writing Task: Giving advice in an email

Digibook Video Activity: Spots and stripes

Study Skills: Where does the time go?

Unit 6: Speed

Reading Texts

1) Hurry up and slow down! / Sociology

2) Keeping up with the Tarahumara /Anthropology

Reading Skills

Close: Distinguishing facts from opinions

Close: Identifying tone

Vocabulary Skill: Organizing new words: adjectives and adverbs

Grammar: Comparative forms of adjectives and adverbs

Writing Skill: Using commas and colons

Writing Task: Making a comparison

Digibook Video Activity: A need for speed

Study Skills: Keeping a journal

Unit 7: Vision

Reading Texts

1) Is seeing really believing? / Biology

2) Color and flags / Semiotics

Reading Skills

Global: Scanning

Close: Using a chart to organize your notes

Vocabulary Skill: Adding suffixes to change verbs into nouns

Grammar: Count and non-count nouns 
Writing Skill: Writing complete sentences

Writing Task: Describing colors

Digibook Video Activity: Learning to see

Study Skills: Studying with others

Unit 8: Extremes

Reading Texts

1) Earth's final frontier / Engineering

2) Super Sherpa / Environmental Studies

Reading Skills

Close: Finding similarities and differences

Global: Identifying the source

Vocabulary Skill: Understanding compound words

Grammar: Expressing ability

Writing Skill: Using transitions to add and emphasize information

Writing Task: Giving your opinion

Digibook Video Activity: Pushing the limits

Study Skills: Using computers for effective study

Unit 9: Life

Reading Texts

1) Coming of age / Anthropology

2) Gardening 380 kilometers above Earth / Botany

Reading Skills

Close: Summarizing

Close: Identifying reasons

Vocabulary Skill: Finding the correct definition of a word

Grammar: The simple past tense

Writing Skill: Using transitions to sequence events

Writing Task: Describing a memorable day

Digibook Video Activity: Saving the bees

Study Skills: Making the most of your dictionary

Unit 10: Work

Reading Texts

1) The farmer's lazy son / Literary studies

2) Leave it for the robot / Technology

Reading Skills

Close: Sequencing

Close: Reading charts and graphs

Vocabulary Skill: Using collocations

Grammar: Future forms

Writing Skill: Using parallel structure

Writing Task: Describing your future

Digibook Video Activity: Work and motivation

Study Skills: Making the most of the library 


\section{Unit Components}

\section{VOCABULARY REVIEW}

Pre-teaching essential vocabulary which appears in both texts within the unit.

\section{BEFORE YOU READ}

These introductions to the reading topics prepare students for the upcoming subject matter.

\section{GLOBAL READING}

Global reading is the first time the students will read the text; encouraging them to engage with the big issues and the overall picture.

\section{SKILLS BOXES}

These focus on the newly-presented skill, why it's important and how to do it. They also highlight reading tips.

\section{CLOSE READING}

Following on from Global reading is Close reading. This is an in-depth detailed analysis of the text.

\section{READING EXCERPTS}

Interesting and original topics make up the reading excerpts in Skillful.

\section{DEVELOPING CRITICAL THINKING}

Developing critical thinking is a chance to reflect on issues presented in the text.

\section{SENTENCE FRAMES}

Add support and help for students who lack confidence with their speaking skills.

\section{SECTION OVERVIEW}

Giving students the context within which they are going to study the productive skills.

SKILLS BOXES

Highlighting witting advice.

\section{FORM AND FUNCTION}

Notes on form and function match up with listening \& speaking grammar in the parallel unit.

\section{END OF UNIT TASK}

Comprehensive end-of-unit task with a noticing exercise for students to identify key features.

\section{GUIDED PRACTICE}

Guides students through the stages of a writing task.

\section{WRITING STAGES}

Gives students support through the stages of the writing process. 
STUDY SKILLS WITH STELLA COTTRELL

Information on study skills features of the end of every unit. Some of these pages showcase a task from Stella Cattrell's bestselling title "The Study Skills Handbook".

\section{STUDY TIPS}

Stella offers students useful and memorable tips to improve their studying methods through selfreflection and critiquing.

\section{STUDY SKILLS SCENARIOS}

Using original material, the other end-of-unit study skills task give students a positive or negative scenario to work through. This provides them with the opportunity for personal performance reflection.

\subsection{Discussion}

To use this textbook teacher should encourage students to ask questions and interact, as learning English is not a passive skill. Many of the tasks and exercises involve pair work, group work, and whole-class discussion. Working with others helps students solidify their understanding and challenge and expand their ability to think critically.

Teacher also should personalize the material and help students to make connections between the texts in their book and their own home, community and country. Bring in outside material from local sources when it's relevant, making sure it fits the unit topics and language.

The instructor who uses this book should provide a lot of practice by having students do each exercise several times, with different partners. Review exercises and material from previous units. Use the Skillful digibook to develop the skill presented in the Student's book. Students should complete the additional activities on a computer outside of class to make even more progress. Assign frequent manageable review tasks for homework.

Teacher should provide many opportunities for review to remind students of the skills, grammar, and vocabulary they learned in previous units. Students should study a little bit each day, not just before tests.

Learning languages take time and practice. Students must be patient with themselves as they put in the necessary time and effort. They should set and check goals. Periodic assessments the teacher can print, such as the unit tests, progress tests, and end test on the Digibook let students see their own progress and measure how much they've learned, so they can feel proud of their skills development.

\section{Conclusions \& Recommendations}

\subsection{Conclusion}

Academic success requires so much more than memorizing facts. It takes skills. This means that a successful student can both learn and think critically. Skillful: Reading \& Writing, Student's 
Book 1 helps teachers prepare their students for academic work in English by teaching not only language - vocabulary and grammar - but the necessary skills to engage with topics, texts, and discourse with classmates. Skillful: Reading \& Writing, Student's Book 1 also offers; a comprehensive digital component including a page-faithful Digitbook and Skillful practice area with interactive activities and video material, two opportunities in each unit to engage critically with issues within texts and to consider concepts beyond the superficial meaning, systematic development of practical study skills through realistic scenarios, critical thinking skills, such as evaluating and synthesizing information. To conclude and answer research question, this textbook is appropriate to teach Thai university EFL students after considering by the researcher (Hughes, 2013).

\subsection{Recommendation}

Teachers may consider adapting materials in a way so as to match the learner's local need and interests. Social and culture contents are also concerned to insert to serve target learners.

There should be a survey on whether the content of Skillful: Reading \& Writing, Student's Book 1 is suitable for teaching and learning of a certain group of learners by considering students' needs and interests.

There should be research on whether the content of the textbook meets the objectives of a certain EFL/ESL course to be achieved in the views of teachers.

There should be content analysis research of another book in the series of "Skillful".

There should be comparative research for content analysis of two interesting textbooks used for the same target group of learners.

\section{References}

[1] Breen. M. P. (1985). The social context of language learning: a neglected situation? Studies in Second Language Acquisition.

[2] Candlin, C. N. (1982). Principles and practice in communicative language teaching, Waiju Jiaoxue Yu Janjiu, 4, Beijing Institute of Foreign Languages.

[3] Crawford, J. (2002). The Role of Materials in the Language Classroom: Finding the Balance. In J. Richards \& W. Renandya. Methodology in Language Teaching: an Anthology of Current Practice. Cambridge: Cambridge University Press.

[4] Hughes, H. S. (2013). Skillful Reading \& Writing, Teacher's Book 1. Macmillan Education.

\footnotetext{
*Corresponding author.

E-mail address: nootprapa@gmail.com
} 